\title{
Unit Produksi dan Jasa sebagai Edupreneurship
}

\author{
Desy Anggreani ${ }^{1}$, Sudarmiatin $^{1}$, Suharto $^{1}$ \\ ${ }^{1}$ Pendidikan Bisnis dan Manajemen-Universitas Negeri Malang
}

\begin{abstract}
INFO ARTIKEL
\section{Riwayat Artikel:}

Diterima: 20-02-2019

Disetujui: 25-07-2019

\section{Kata kunci:}

production and service units; edupreneurship;

SWOT analysis:

unit produksi dan jasa;

edupreneurship;

analisis SWOT
\end{abstract}

\author{
Alamat Korespondensi: \\ Desy Anggreani \\ Pendidikan Bisnis dan Manajemen \\ Universitas Negeri Malang \\ Jalan Semarang 5 Malang \\ E-mail: desyanggreani9@gmail.com
}


Berdasarkan alasan tersebut diperlukan upaya untuk menyiapkan lulusan yang siap kerja dan kemampuan untuk membuka usaha sendiri. Salah satu upaya yang dapat dilakukan adalah dengan membangun Edupreneurship yaitu memasukkan aspek kewirausahaan dalam bidang pendidikan dengan melaksanakan usaha kreatif atau inovasi,(Agrawal, 2013; Ananda \& Mukhadis, 2016) yang dilakukan oleh sumber daya di sekolah (Sofyan, Muladi, Sugandi, 2018; Rusnani, 2012) sehingga meningkatkan kompetensi siswa dengan menggunakan teknologi (Lăcătuş \& Stăiculescu, 2016) baik pada proses produksi dan pemasarannya sehingga menambah pemasukkan sekolah.

Salah satu bentuk edupreneurship di sekolah menengah kejuruan ialah unit produksi dan jasa sekolah yang merupakan bagian yang tidak terpisahkan dari SMK sesuai dengan arahan Direktorat Pembinaan Sekolah Menengah Kejuruan Tahun 2007 bahwa fungsi dari UPJ sebagai wahana kegiatan praktik pendidikan dan latihan yang berorientasi pada dunia kerja dan wadah untuk mengembangkan jiwa kewirauasahaan pada warga sekolah. Salah satu kegiatan di unit produksi dan jasa SMKN 2 Batu ialah budidaya jambu kristal yang telah memiliki lahan jambu kristal yang siap berproduksi. Berdasarkan observasi awal, pengelolaan jambu kristal dilakukan oleh koordinator UPJ jambu kristal dan tukang kebun. Keterlibatan siswa baru dilakukan akhir bulan September 2018, keterlibatan siswa berdasarkan minat siswa dan waktu pengerjaan disesuikan waktu kosong dari siswa (jam kosong dan waktu pulang sekolah). Hal ini menyebabkan siswa mengalami beberapa kendala dalam proses budidaya jambu kristal: sanitasi di lahan Jambu Kristal tidak baik dengan banyaknya gulma yang tumbuh dan lahan yang basah sehingga buah rusak dan busuk karena terserang hama lalat buah. siswa tidak menerapkan K3 pada saat pencampuran dan penyemprotan pestisida sehingga mengganggu produktivitas Jambu Kristal. Adapun hasil dari UP jambu kristal ialah buah jambu kristal segar dan bibit jambu kristal.

Berdasarkan uraian-uraian masalah di atas, maka penelitian ini difokuskan untuk mengembangkan unit produksi jambu kristal sebagai Edupreneuship pada SMK Negeri 2 Batu dengan bantuan Analisis SWOT (Sudarmiatin \& Suharto, 2016) diharapkan menghasilkan strategi-strategi untuk mengembangkan UPJ sebagai Edupreneurship yaitu suatu usaha atau aktivitas produksi yang kreatif atau inovatif dilakukan oleh sumber daya di sekolah untuk meningkatkan kompetensi siswa menghasikan produk yang berkualitas dan melatih berwirausaha dengan menjaga kelangsungan kegiatan unit produksi melalui penggunaan teknologi baik pada proses produksi dan pemasarannya sehingga diharapkan memperoleh keuntungan optimal bagi sekolah. Adapun fokus dari penelitian ini mengembangkan strategi Unit Produksi sebagai Edupreneurship yaitu wahana pelatihan bekerja dan berwirausaha bagi siswa dengan melakukan usaha kreatif dan inovatif, penggunaan teknologi pada saat budidaya jambu kristal serta pemasarannya.

\section{METODE}

Penelitian ini menggunakan pendekatan kualitatif deskriptif dengan rancangan studi kasus dengan bantuan analisis SWOT. Dalam penelitian kualitatif, peneliti sebagai instrumen kunci dalam upaya pengumpulkan data-data. Penelitian ini dilaksanakan di unit usaha dan jasa SMKN 2 Batu unit produksi dan jasa SMKN 2 Batu. Jl Pandanrejo 39 A Bumiaji kota Batu. Sumber data dari penelitian ini ialah wawancara, catatan lapangan (observasi), dan foto (dokumentasi). Informan dalam penelitian ini Kepala SMKN 2 Batu, Kepala unit produksi SMKN 2 Batu, koordinator usaha jambu kristal, koordinator pemasaran, dan siswa. Adapun proses untuk pengambilan keputusan strategi pengembangan unit produksi sebagai edupreneurship di SMKN 2 Batu dapat dilihat pada gambar 1 .

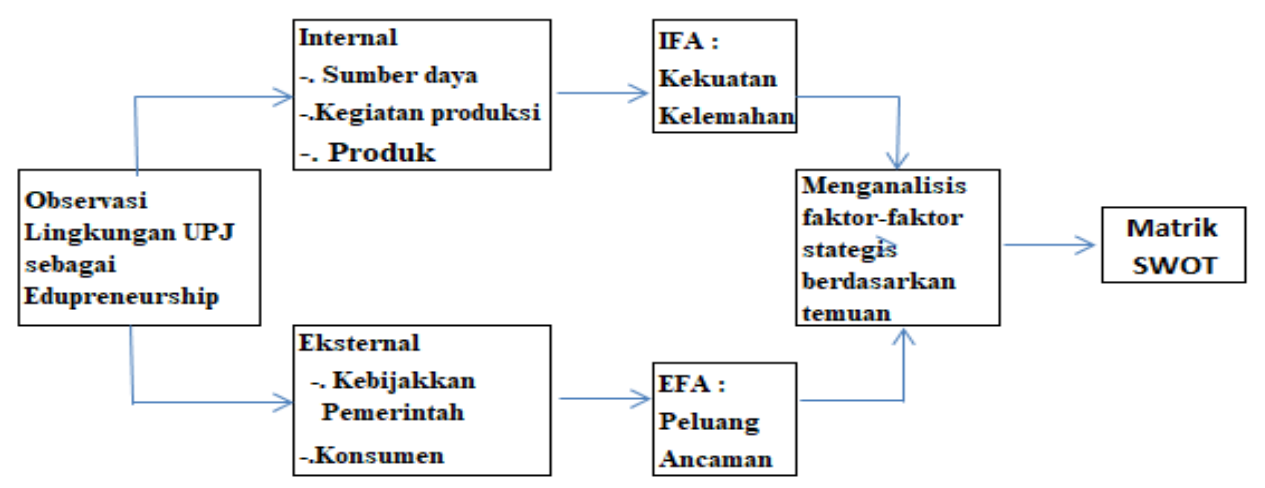

(Sumber: Modifikasi dari Hungger \& Wheelen, 2003)

Gambar 1. Proses Pengambilan Keputusan Strategi Unit Produksi sebagai Edupreneurship 


\section{HASIL}

\section{Analisis Kondisi Internal dan Eksternal Unit Produksi dan Jasa SMKN 2 Batu}

Analisis kondisi internal berdasarkan kekuatan dan kelemahan yang nilai skornya diperoleh dari bobot dan rating yang sesuai dengan kepentingan lembaga.

Tabel 1. Kondisi Internal Unit Produksi Jambu Kristal SMKN 2 Batu

\begin{tabular}{|c|c|c|c|}
\hline Analisis Faktor Internal & \multirow[t]{2}{*}{ Bobot } & \multirow[t]{2}{*}{ Rating } & \multirow[t]{2}{*}{ Skor } \\
\hline Kekuatan : & & & \\
\hline 1. Persamaan tujuan UPJ antara Kepala Sekolah, Kordinator UPJ, Kordinator Jambu Kristal & 0,12 & 4 & 0,48 \\
\hline 2. Lahan Jambu Kristal Siap Berproduksi & 0,1 & 4 & 0,4 \\
\hline Produk: Jambu dan Bibit & 0,09 & 3 & 0,27 \\
\hline 4. Promosi Produk & 0,09 & 4 & 0,36 \\
\hline 5. Siswa sebagai pelaksana kegiatan budidaya Jambu Kristal & 0,12 & 4 & 0,48 \\
\hline Jumlah & 0,52 & 19 & 1,99 \\
\hline \multicolumn{4}{|l|}{ Kelemahan : } \\
\hline 1. Cara Perekrutan Siswa yang belum memiliki aturan yang jelas & 0,12 & 2 & 0,24 \\
\hline Waktu kegiatan siswa di UPJ Jambu Kristal & 0,12 & 2 & 0,24 \\
\hline Pengunaan teknologi pada Budidaya jambu Kristal & 0,09 & 1 & 0,09 \\
\hline Belum adanya Manajemen Produksi & 0,09 & 2 & 0,18 \\
\hline Kurangnya perawatan pada Jambu Kristal & 0,03 & 1 & 0,03 \\
\hline 6. Promosi di Media Sosial tidak terupdate & 0,03 & 1 & 0,03 \\
\hline Jumlah & 0,48 & 9 & 0,81 \\
\hline Jumlah Total & 1 & & 1,18 \\
\hline
\end{tabular}

(Sumber: Diolah Peneliti dan Kepala Unit Produksi dan Jasa SMK Negeri, 2018).

Dari analisis faktor internal diperoleh untuk Unit Produksi memiliki kekuatan yang lebih besar dibandingkan faktor kelemahananya dengan total nilai faktor internal sebesar 1,18. Analisis faktor eksternal berdasarkan faktor peluang dan ancaman yang skornya diperoleh dari bobot dan rating yang sesuai dengan kepentingan lembaga. Dari analisis faktor eksternal diperoleh unit Produksi SMKN 2 Batu, memiliki peluang yang lebih besar dibandingkan faktor ancaman dengan total nilai faktor eksternal sebesar 1,15.

Tabel 2. Analisis Kondisi Eksternal Unit Produksi dan Jasa SMKN 2 Batu

\begin{tabular}{|c|c|c|c|c|}
\hline \multicolumn{2}{|r|}{ Analisis Faktor Eksternal } & \multirow{2}{*}{ Bobot } & \multirow{2}{*}{ Rating } & \multirow{2}{*}{ Skor } \\
\hline Peluang & & & & \\
\hline 1. & Kebijakan pemerintah terhadap keberadaan UPJ & 0,1 & 4 & 0,4 \\
\hline 2. & Prospek jambu kristal & 0,1 & 4 & 0,4 \\
\hline 3. & Penjualan produk lain selain buahnya yang dijual & 0,15 & 4 & 0,6 \\
\hline 4. & Penjualan memiliki pangsa pasar tersendiri & 0,15 & 3 & 0,45 \\
\hline 5. & Kerjasama dengan pihak lain & 0,05 & 3 & 0,15 \\
\hline Jumlah & & 0,55 & 18 & 2 \\
\hline \multicolumn{5}{|c|}{ Ancaman } \\
\hline 1. & Tidak adanya kerjasama dengan DU/Di yang sejenis & 0,05 & 2 & 0,1 \\
\hline 2. & Kurangnya anggaran untuk perluasaan lahan Jambu Kristal & 0,05 & 1 & 0,05 \\
\hline 3. & Tidak dilibatkanya Guru Produktif ATPH pada perawatan Jambu Kristal & 0,15 & 2 & 0,3 \\
\hline 4. & Kompetitor yang layanan penjualan dengan "petik buah" & 0,1 & 2 & 0,2 \\
\hline 5. & Kompetitor yang menerapkan pertanian organik & 0,1 & 2 & 0,2 \\
\hline Jumlah & & 0,45 & 9 & 0,85 \\
\hline Jumlah & Total & 1 & & 1,15 \\
\hline
\end{tabular}

(Sumber: Diolah Peneliti dan Kepala Unit Produksi da Jasa SMK Negeri, 2018) 


\section{Analisis SWOT sebagai Perumusan Strategi}

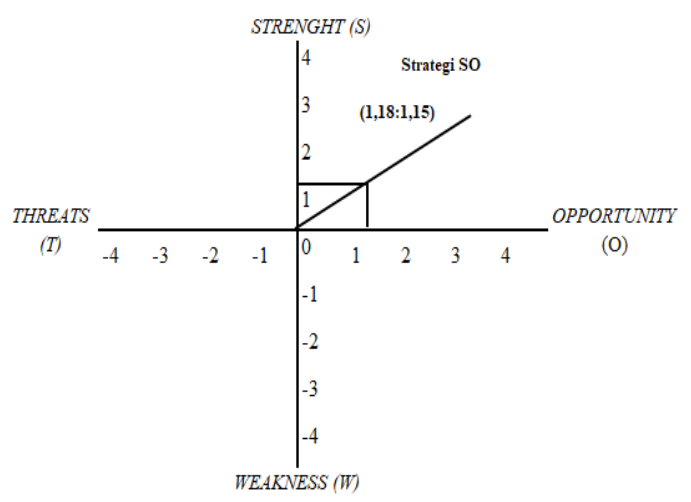

Sumber: Diolah Peneliti

\section{Gambar 2. Matrik SWOT}

Berdasarkan analisis faktor internal dan eksternal pada tabel $1 \& 2$, dapat ditentukan koordinat matriks SWOT : 1,18: 1,15 (Sudarmiatin \& Suharto, 2016) dapat dilihat pada gambar 2. Berdasarkan gambar 1, dapat dilihat bahwa strategi pengembangan Unit Produksi dan Jasa sebagai Edupreneurship pada SMKN 2 Batu yang sesuai menggunakan strategi SO (Strength - Opportunity) yaitu menggunakan dan memanfaatkan keuntungan dari peluang eksternal yang ada dengan memaksimalkan kekuatan internal yang dimiliki UPJ jambu kristal (David, 2009). Adapun penjabaran strategi SO akan ditampilkan pada matrik SWOT (tabel 3).

\section{PEMBAHASAN}

\section{Analisis Kondisi Internal dan Eksternal Unit Produksi dan Jasa SMKN 2 Batu}

Unit Produksi dan Jasa di SMKN 2 Batu memiliki faktor-faktor untuk mewujudkan lulusan yang siap kerja dan memiliki sikap kemandirian yang dapat diandalkan. Salah satu upaya yang dilakukan adalah membangun edupreneurship dalam rangka meningkatkan kompetensi siswa dengan melatih bekerja pada unit produksi dan berwirausaha dengan menjaga keberlangsungan unit produksi melalui pengembangan teknologi budidaya dan pemasaran. setelah dilakukan analisis faktor internal, diperoleh kekuatan dengan score 1,99 lebih besar daripada faktor kelemahan dengan score 0,81, maka dapat diartikan bahwa unit produksi memiliki kekuatan-kekuatan internal yang dapat dikembangkan sebagai edupreneurship. Adapun kekuatan yang memiliki skor tertinggi untuk pengembangan unit produksi menjadi edupreneurship ialah persamaan tujuan antara kepala sekolah, kepala UPJ, koordinator jambu kristal yang menginginkan unit produksi sebagai tempat pelatihan bekerja siswa dalam mengaplikasikan ilmu yang diperoleh di kelas dan tempat untuk menjual hasil/produk dari kompetensi siswa tersebut. dengan berlatih bekerja siswa akan mempunyai bekal dan dapat beradaptasi dengan lingkungan kerja. Apalagi tantangan pada dunia pertanian dengan kondisi cuaca yang tidak menentu akan meningkatkan serangan hama dan penyakit pada lahan pertanian sehingga memerlukan inovasi inovasi dalam budidaya pertanian. Siswa juga akan berlatih berwirausaha dengan menjaga keberlangsungan kegiatan di UPJ jambu kristal dengan pengembangan layanan penjualan, melakukan promosi di media-media sosial dengan memproduksi jambu kristal organik.

Pada faktor kelemahan skor tertinggi ialah pada cara perekrutan siswa dan waktu pelaksanaan kegiatan siswa di UP jambu kristal. Siswa baru dilibatkan pada kegiatan di UPJ jambu kristal sekitar akhir September sehingga aktivitas yang dapat dilatih adalah pemupukan, pemangkasan, pembungkusan buah dan pengendalian hama dan penyakit, sedangkan pembibitan dengan mencangkok masih belum dilakukan. Waktu kegiatan siswa di lahan Jambu Kristal dilakukan pada jam kosong atau pada saat pulang sekolah menyebabkan siswa ketinggalan pembelajaran atau siswa telah lelah melakukan kegiatan di UPJ jambu kristal yang menyebabkan penundaan kegiatan perawatan jambu kristal apabila siswa ulangan atau ujian. Hal ini merupakan indikator bahwa UPJ belum menerapkan manajemen produksi yang baik. Menurut (Alif et al., 2018; Sukmawaty \& Sugiyono, 2016). Manajemen produksi akan menjamin keberlangsungan kegiatan UPJ jambu kristal yang terdiri dari perencanaan ( rencana kegiatan yang dilakukan), jurnal kegiatan dan evaluasi kegiatan di UPJ jambu kristal. Penundaan pada kegiatan produksi akan menurunkan produktivitas tanaman. Keterlambatan pemberian pupuk, pembungkusan buah, pengontrolan dan penanganan buah yang terkena hama dan penyakit akan menggurangi kualitas buah dan menyebabkan kegagalan panen (Pratidina, Syamsun, \& Wijaya, 2015). 
Pada analisis faktor eksternal menunjukkan besarnya peluang yaitu 2,00 dan hambatan sebesar 0,85, maka dapat diartikan bahwa terdapat peluang besar untuk menjadikan Unit Produksi dan Jasa sebagai edupreneurship. Adapun faktor peluang pada pengembangan UPJ sebagai edupreneurship ialah siswa dapat mengembangkan produk yang dijual selain buah jambu kristal segar, pembibitan dengan cara mencangkok dan pembuatan pupuk organik dari hasil pangkasan daun-daun jambu kristal merupakan kompetensi yang dapat dilatih pada siswa.

\section{Tabel 3. Tabel Matrik SWOT}

\begin{tabular}{|c|c|c|}
\hline PELUANG & KEKUATAN & KELEMAHAN \\
\hline \multirow{18}{*}{$\begin{array}{l}\text { Kebijakan pemerintah } \\
\text { Prospek Jambu Kristal } \\
\text { Terdapat produk lain selain buahnya } \\
\text { yang dijual. } \\
\text { Penjualan memiliki pangsa pasar } \\
\text { tersendiri } \\
\text { Kerjasama dengan pihak lain }\end{array}$} & Persamaan tujuan UPJ antara Kepala & Cara Perekrutan Siswa \\
\hline & Sekolah, Kordinator UPJ, Kordinator Jambu & Waktu Pelaksanaan \\
\hline & Kristal & Belum adanya Manajemen Produksi \\
\hline & Lahan Jambu Kristal Siapa Berproduksi & Kurangnya perawatan Jambu Kristal \\
\hline & Produk: Jambu dan Bibit & Pengunaan teknologi \\
\hline & Promosi Produk & promosi di facebook yang tidak update \\
\hline & $\begin{array}{l}\text { Siswa sebagai pelaksana kegiatan budidaya } \\
\text { Jambu Kristal }\end{array}$ & \\
\hline & $\begin{array}{l}\text { Pedoman kegiatan produksi Unit Produksi } \\
\text { yang mengaju Kurikulum }\end{array}$ & $\begin{array}{l}\text { Membuat aturan terulis cara perekutan siswa, } \\
\text { waktu pelaksanaan kegitan UPJ sehingga tidak }\end{array}$ \\
\hline & Melakukan pengembangan produk dan & menggangu kegiatan pembelajaran. \\
\hline & penggunaan teknologi terbaru pada & Penerapan manajemen produksi dan \\
\hline & budidaya jambu Kristal (organic) & keterlibatan guru produktif pada lahan jambu \\
\hline & Pengembangan pangsa pasar dengan media & kristal \\
\hline & promosi di dunia maya dan perbaikkan & Peningkatan budidaya Jambu Kristal untuk \\
\hline & budidaya Jambu Kristal secara organik & meningkatkan pangsa pasar produk jambu \\
\hline & Peningkatan keterlibatan siswa dalam & kristal \\
\hline & $\begin{array}{l}\text { budidaya dan pemasaran (layanan } \\
\text { penjualan, promosi di dunia maya) }\end{array}$ & $\begin{array}{l}\text { Melakukan perbaikkan promosi di media social } \\
\text { mengenai keunggulan jambu Kristal }\end{array}$ \\
\hline & Meningkatkan kerjasama dengan pihak & Meningkatkan kerjasama dengan pihak lain \\
\hline & $\begin{array}{l}\text { DU/DI sejenis untuk transfer ilmu dan } \\
\text { teknologi budidaya jambu kristal dan } \\
\text { menjaga kontinyuitas produk jambu }\end{array}$ & \\
\hline ANCAMAN & Peningkatan dengan DU/DI sebagai mitra & Memasukkan kegiatan Unit produksi pada \\
\hline \multirow{8}{*}{$\begin{array}{l}\text { Tidak adanya kerjasama dengan DU } \\
\text { yang sejenis } \\
\text { Kurangnya anggaran untuk } \\
\text { perluasaan lahan Jambu Kristal } \\
\text { Tidak terlibatnya Guru Produktif } \\
\text { ATPH pada budidaya Jambu Kristal } \\
\text { Kompetitor yang layanan penjualan } \\
\text { dengan "petik buah" } \\
\text { Kompetitor yang menerapkan } \\
\text { pertanian organik }\end{array}$} & dalam penjualan Jambu Kristal & pembelajaran \\
\hline & Penambahan modal untuk perluasaan lahan & Penerapan manajemen produksi dan melibatkan \\
\hline & jambu Kristal & guru produktif pada Budidaya Jambu Kristal \\
\hline & Peningkatan keterlibatan guru produktif & secara organik untuk meningkatkan daya pngsa \\
\hline & pertanian sebagai pembimbing pada & pasar produk jambu kristal \\
\hline & produksi (budidaya jambu Kristal) & Perbaikan promosi dan penjualan produk jambu \\
\hline & $\begin{array}{l}\text { Meningkatan promosi dan penjualan } \\
\text { produk jambu kristal organik dengan uji }\end{array}$ & $\begin{array}{l}\text { kristal organik dengan uji laboraturium bahwa } \\
\text { produk sudah bebas dari pupuk dan pestisida }\end{array}$ \\
\hline & $\begin{array}{l}\text { laboraturium bahwa produk sudah bebas } \\
\text { dari pupuk dan pestisida anorganik }\end{array}$ & anorganik \\
\hline
\end{tabular}

Pada kolom ancaman, nilai terbesar diperoleh belum terlibatnya guru produktif pertanian (ATPH) sebagai pembimbing pada proses produksi. Hal ini menyebabkan proses budidaya jambu kristal mengalami beberapa kendala, seperti (1) sanitasi di lahan jambu kristal tidak baik dengan banyaknya gulma yang tumbuh dan lahan yang basah sehingga terserang hama lalat buah dan buah banyak yang busuk, (2) siswa tidak menerapkan K3 pada saat pencampuran dan penyemprotan pestisida, sedangkan pada peraturan penggunaan Laboraturium Arigribisnis Tanaman, peserta didik diharuskan memakai persyaratan K3 dalam kegiatan praktikum, dan (3) belum berproduksinya jambu kristal semenjak kegiatan unit produksi dilakukan oleh siswa. Maka pembimbingan guru Produktif ATPH sangat dibutuhkan pada budidaya jambu kristal di UPJ jambu kristal.

\section{Posisi dan Strategi Pengembangan Unit Produksi dan Jasa SMKN 2 Batu sebagai Edupreneurship}

Matrik SWOT akan menghasilkan berbagai strategi untuk mengembangkan unit produksi dan jasa SMKN 2 Batu sebagai edupreneurship, yaitu strategi SO, WO, ST, dan WT. Adapun posisi UPJ sebagai edupreneurship berada pada koordinat 1,13 : 1,25 yang berada pada kuadran SO yang memiliki arti bahwa posisi unit produksi dan jasa SMKN 2 Batu sebagai edupreneurship berada pada posisi yang sangat bagus untuk memanfaatkan berbagai kekuatan internalnya untuk menarik keuntungan dari peluang peluang eksternal, mengatasi kelemahan internal, dan berbagai ancaman eksternal. Adapun strategi SO yang telah dikembangkan berdasarkan matriks SWOT sebagai berikut. 
Pertama, pembuatan pedoman kegiatan produksi unit produksi yang mengaju kurikulum. Pembuatan pedoman kegitan unit produksi yang mengaju pada kurikulum akan menjadi menjadi landasan bagi program kerja pada masing masing koordinator di unit produksi dan jasa. Pedoman kegiatan UPJ harus disepakati antara kepala sekolah, Kepala UPJ, dan Koordinator UPJ dan kurikulum. Disinilah peran penting kepala sekolah sebagai pemegang kebijakan di SMK (Maghfiroh, 2015). Dengan adanya Program kegiatan produksi yang mengaju kurikulum, maka kegitan UPJ dapat dilaksanakan waktu pembelajaran sehingga ada pengawasan oleh guru produktif dan koordinator UPJ jambu kristal terhadap siswa. Guru Produktif akan memberikan arahan bagaimana proses budidaya yang baik sesuai SOP dengan mempraktikkan ilmu-ilmu yang diterima pada saat pembelajaran dan dapat memberikan masukkan pada budidaya jambu kristal apabila mengalami kendala. Apalagi kondisi dengan kondisi cuaca yang tidak menentu pada saat ini, diperlukan inovasi-inovasi dalam proses budidaya untuk meningkatkan kualitas jambu kristal. Koordinator UPJ akan mengarahkan siswa untuk bagaimana pengelolaan usaha yang profesionaal untuk menghasilkan produkproduk berkualitas dan dibutuhkan oleh masyarakat. Dengan memasukkan kegiatan UPJ pada kurikulum pembelajaran sehingga pencapaian tujuan pembelajaran siswa tercapai, (Alif et al., 2018; Rusnani, 2012). Dengan adanya jadwal kegiatan yang tertulis maka kegiatan perawatan Jambu Kristal tidak menggangu pembelajaran dan semua siswa dilibatkan dalam kegiatan di UPJ secara bergiliran sehingga memperoleh tambahan kompetensi pada proses budidaya pada Jambu Kristal.

Kedua, melakukan pengembangan produk dan penggunaan teknologi terbaru pada budidaya jambu kristal (organic). Produk-produk yang dihasilkan pada UPJ jambu kristal dapat dikembangkankan lebih beragam. jambu kristal dapat dicangkok untuk menghasilkan bibit yang berkualitas dan cepat berbuah. Hasil dari pemangkasan daun daun jambu kristal yang telah tua dapat dijadikan kompos untuk meningkatkan kesuburan tanaman dan dapat dijual sebagai pupuk organik. Pada hasil observasi, kondisi sanitasi yang buruk pada lahan jambu kristal akan meningkatkan kelembaban yang tinggi sehingga serangan hama dan penyakit akan meningkat maka perlu dilakukan perbaikan teknik budidaya karena dapat berbuah sepanjang tahun (Pratidina et al., 2015). Maka diharapkan siswa dengan bantuan guru akan berinovasi dalam hal budidaya dengan menggunakan teknologi terbaru untuk memperoleh produk yang berkualitas. Adanya pola hidup sehat yang akrab dengan lingkungan menginginkan makanan yang aman dikonsumsi, maka perlu mengembangkan sistem pertanian organik yaitu penggunaan pupuk organik (kompos, pupuk kandang) agar memperoleh buah kristal jambu organik yang aman dikonsumsi (Mayrowani, 2012).

Ketiga, memperluas pangsa pasar dengan media promosi di dunia maya. Produk dari UPJ memiliki pangsa pasar yang jelas yaitu seluruh warga sekolah yaitu guru, siswa, dan karyawan. Produk Jambu Kristal, biasanya dijual pada guru ataupun tamu yang berkunjung di sekolah. Untuk memperluas pangsa pasar dapat dilakukan dengan menggunakan brosur, video, dan mengikuti pameran pameran, kegiatan promosi merupakan bagian dari baur pemasaran yang digunakan memberitahukan dan membujuk (Kotler, 1997) agar konsumen dapat mengetahui keunggulan dari jambu Kristal. Media sosial yang digunakan adalalah facebook dengan link Upj Jaya dan Instragram dengan link Smkn2Batu telah dibuat video promosi oleh tim pemasaran yang dilakukan pada 10 Oktober 2017. Namun, ditemukan ada beberapa kekurangan pada media promosi di facebook, yakni tidak ada informasi kegiatan terbaru di UPJ SMKN 2 Batu. Maka perlu adanya perbaikkan promosi dengan melibatkan siswa dan guru multimedia agar konten-konten promosi menjadi lebih menarik dan informatif.

Keempat, peningkatan keterlibatan siswa dalam budidaya dan pemasaran (layanan penjualan, promosi di media soasial). Kegiatan siswa di UPJ jambu kristal masih terbatas pada proses budidaya jambu kristal, maka perlu ditingkatkan peran siswa di UPJ Jambu Kristal dengan cara dilibatkan dalam proses penjualan. Siswa dilatih untuk menjual jambu kristal di luar lingkungan sekolah yang akan meningkatkan rasa percaya diri dan kemandirian dan belajar untuk mengetahui selera dari pelangganya (Ananda \& Mukhadis, 2016) sehingga bisa menangkap peluang peluang baru usaha dari UPJ Jambu Kristal. Siswa juga dilibatkan dalam kegiatan promosi di media sosial dengan mengupload produk produk UPJ di media sosial yang mereka miliki.

Kelima, meningkatkan kerjasama dengan pihak DU/DI yang sejenis untuk transfer ilmu dan teknologi budidaya jambu kristal dan menjaga kontinyuitas produk jambu. Unit Produksi perlu meningkatkan kerjasama dengan outlet oleh-oleh untuk memasarkan jambu kristal. Menurut (Ananda \& Mukhadis, 2016), kerjasama dengan DUDI akan memberikan ide bisnis baru dan dapat memberikan motivasi dan contoh dalam pengembangan usaha dan bekerjasama dengan pihak swasta publik dan swasta akan meningkatkan penggunaa teknologi pada lulusan pendidikan teknis dan kejuruan (Okoye \& Chijioke, 2013). Di sekitar SMKN 2 Batu terdapat usaha jambu kristal, yaitu UD Bumiaji Sejahtera yang memiliki keunggulan, meliputi (1) telah menerapkan pertanian organik dan (2) petik jambu kristal. Dengan bekerjasama dengan DUDI akan memberikan manfaat pada pengembangan teknologi budidaya dan cara penjualan yang lebih menarik. Praktisi dari Du/Di dapat diundang sebagai guru tamu untuk meningkatkan motivasi siswa, sharing pengalaman, dan inspirasi siswa untuk mengembangkan usaha yang sejenis. Kerjasama dengan usaha yang sejenis juga diperlukan untuk menjaga ketersediaan barang, apabila permintaan pasar sedang meningkat sehingga tidak mengecewakan pelanggan. 


\section{SIMPULAN}

Berdasarkan dari analisis SWOT untuk menentukan Strategi Pengembangan Unit Produksi dan Jasa SMKN 2 Batu sebagai Edupreneurship maka dapat disimpulkan. Berdasarkan analisis kekuatan internal dari Unit Produksi dan Jasa SMKN 2 Batu diperoleh nilai sebesar 1,18 dan analisis faktor eksternal sebesar 1,15 yang berarti pada starategi SO yaitu memanfaatkan seluruh kekuatan untuk merebut dan memanfaatkan peluang sebesar-besarnya Unit Produksi dan Jasa SMKN 2 Batu sebagai Edupreneurship sangat terbuka lebar.

Adapun strategi SO yang telah dikembangkan berdasarkan matriks SWOT, meliputi (1) pedoman kegiatan produksi Unit Produksi yang mengaju Kurikulum, (2) melakukan pengembangan produk dan penggunaan teknologi terbaru pada budidaya jambu kristal (organic), (3) pengembangan pangsa pasar dengan media promosi di dunia maya dan perbaikkan budidaya Jambu kristal secara organik, (4) peningkatan keterlibatan siswa dalam budidaya dan pemasaran (layanan penjualan, promosi di dunia maya), dan (5) meningkatkan kerjasama dengan pihak DU/DI sejenis untuk transfer ilmu dan teknologi budidaya jambu kristal dan menjaga kontinyuitas produk jambu.

Adapun saran yang dapat diberikan oleh peneliti bagi pengembangan unit produksi dan jasa SMKN 2 Batu sebagai Edupreneurship. Perlu adanya kerjasama antara pengelola Unit Produksi dan Jasa dengan guru yang sebidang dengan kegiatan atau produk yang dihasilkan sebagai quality control. Pemilihan produk yang dihasilkan UPJ berdasarkan kebutuhan pasar dan memperluas jaringan pemasaran sehingga bermanfat bagi masyarakat sekitar.

\section{DAFTAR RUJUKAN}

Agrawal, R. (2013). How to Identify and Select a Business Opportunity and Then Implement the Business Idea ? A Case on Edupreneurship in. Journal of Business Study, 4(4), 176-183.

Ananda, A. F., \& Mukhadis, A. (2016). Production Unit as Edupreneurship, Cooperation Business, and Industrial World with the School for the Development of Vocational Student Entrepreneurship Mindset. AIP Conference Proceedings. https://doi.org/10.1063/1.4965782

David, F. R. (2009). Manajemen Strategis Konsep. Jakarta: Salemba Empat.

Kotler, P. (1997). Manajemen Pemasaran Analisis Perencanaan, Implementasi dan Pengendalian (terjemahan Jaka Wasana). Jakarta: Salemba Empat.

Lăcătuş, M. L., \& Stăiculescu, C. (2016). Entrepreneurship in Education. International Conference Knowledge-Based Organization. https://doi.org/10.1515/kbo-2016-0075

Maghfiroh, D. N. (2015). Manajemen Unit Produksi di Sekolah sebagai Sarana Pembelajaran. Jurnal Manajemen Pendidikan, 24(6), 583-590.

Mayrowani, H. (2012). Pengembangan Pertanian Organik di Indonesia The Development of Organic Agriculture In Indonesia. Pusat Sosial Ekonomi dan Kebijakan Pertanian, 30(2), 91-108. https://doi.org/10.21082/fae.v30n2.2012.91-108

Okoye, K. R. E., \& Chijioke, O. P. (2013). Private-Public Partnership and Technical Vocational Education and Training (TVET) in a Developing Economy. Oman Chapter of Arabian Journal of Business and Management Review, 34(979), 111.

Pratidina, R., Syamsun, M., \& Wijaya, N. H. (2015). Analisis Pengendalian Mutu Jambu Kristal dengan Metode Six Sigma do ADC IPB-ICDF Taiwan Bogor. Jurnal Manajemen dan Organisasi, VI(1), 1-18.

Rusnani. (2012). Sekolah Menengah Kejuruan Negeri the Implementation of the Production/Service Unit in Public Vocational High Schools of the Business. Jurnal Pendidikan Vokasi, 2(November), 338-354.

Sudarmiatin., \& Suharto. (2016). Sustainable Competitive Advantage on SMEs : Bringing Local Product toward Global Market. Journal of Business and Management, 18(7), 46-53. https://doi.org/10.9790/487X-1807034653

Sukmawaty, W. E., \& Sugiyono, S. (2016). Pengembangan Model Manajemen Unit Produksi SMK Program Studi Keahlian Tata Busana di Kabupaten Sleman. Jurnal Pendidikan Vokasi. https://doi.org/10.21831/JPV.V6I2.7793

Sofyan, M. A. H., Muladi., \& Sugandi, R. M. (2018). Faktor-Faktor yang Memengaruhi Keterlaksanaan Unit Produksi SMK pada Program Studi Keahlian Teknik Komputer dan Informatika di Kota Malang. Jurnal Pendidikan; Teori, Penelitian, dan Pengembangan, 3(5), 552-557. 